\title{
SLURRY ACIDIFICATION TECHNIQUES: FIRST STEPS TOWARDS COMPREHENSIVE STUDY IN RUSSIAN CONDITIONS
}

\author{
Roman Uvarov, Natalia Oblomkova, Ivan Freidkin \\ Federal Scientific Agroengineering Centre VIM, Russia \\ rauvarov@gmail.com, oblomkovan@gmail.com, fat3000@mail.ru
}

\begin{abstract}
Introduction of new intensive animal housing practices results in the increased amount of manure produced with a higher share of slurry. Reducing nitrogen emissions from the agricultural activities into the environment is one of the priorities of agroecology. In 2016, ammonia losses to the atmosphere from livestock farming from the territory of the Russian Federation amounted to about 677,000 tons. One of the solutions to this problem is implementation of slurry acidification techniques by adding concentrated sulfuric acid. In the study the prerequisites for application of these techniques in large-scale cattle and pig-rearing complexes in the subjects of the Russian Federation located within the boundaries of the Baltic Sea catchment area were considered; the main features of the Russian legislation related to the treatment of slurry were analysed. In addition, a series of experiments was conducted with the samples of slurry from the Russian farms for preliminary assessment of sulfuric acid demand. With the mathematical model created in the framework of the EU project "Baltic Slurry Acidification", the economic efficiency of slurry acidification techniques on a pilot farm in Russia was determined. The work done showed that the region under consideration had a significant potential for slurry acidification: out of 11.8 million tons of manure produced in the region, 7.4 million tons could potentially be used for this purpose. Slurry acidification techniques have both pros and cons associated, primarily, with the increased risks of emergencies when handling the particularly dangerous substances, sulfuric acid included.
\end{abstract}

Key words: slurry, ammonia emission, sulfuric acid, acidification.

\section{Introduction}

Ensuring environmental safety of production is one of the main aims of the development of the economy of Russia. According to official data, in 2016 ammonia emission from the territory of the Russian Federation is just less than 900 thousand tons [1].

The ammonia emission into the atmosphere provokes ecosystem disturbances, leads to more intensive eutrophication and acidification of waters. As a result, the process of ecosystem degradation starts, and biological diversity decreases. Moreover, ammonia emissions have adverse impacts on human health by contributing to the formation of secondary particulate aerosols [2].

The emission of ammonia leads to the loss of a significant amount of nitrogen, which can be used in various sectors of the economy, in particular in agriculture. Investigations established that more than half of the ammonia in the world is produced by farming [3;4]. In farming about $90 \%$ of emission accounts for operations associated with the utilization of animal and poultry manure. In particular, at the global level, out of 3.6 million tons of $\mathrm{NH}_{3}$, about 2.1 million tons are the emissions from manure processing [5]. Consequently, about 677,000 tons of nitrogen, potentially suitable for the application in crop production with organic fertilizers, are withdrawn from agriculture as gaseous ammonia emission [6]. According to experts, this value is equivalent to the purchase of nitrogen within mineral fertilizers to the amount of 343 million EUR.

Taking into account the emerging trend to increase the animal stock in Russia, a further growth in the amount of nitrogen produced in livestock waste is to be expected and, consequently, its higher loss. Thus, in the period from 2007 to 2017, the number of pigs increased from 16.3 to 23.2 million head, the number of poultry - from 389 to 561.3 million head that was reflected in the level of ammonia emissions (Figure 1) [1;7].

In addition, the emerged transition to intensive technologies in livestock farming associated with the introduction and wider application of new housing practices results in higher share of slurry [8]. Thus, in 2016, in the territory of 6 subjects of Russia within the Baltic Sea catchment area, about 11.8 million tons of animal and poultry manure were produced, of which 7.4 million tons $(62 \%)$ is slurry $[9 ; 10]$.

All this sets before science the task of searching and introducing new, more efficient techniques of slurry processing, aimed at reducing the nitrogen losses and the odour. 
One of these techniques is slurry acidification. Lowering the $\mathrm{pH}$ of slurry to 5.5 reduces ammonia emissions to the values close to zero [11]. This is possible by adding acid to slurry and subsequent homogenization. In the preliminary studies the most effective $\mathrm{pH}$ decrease was observed when using concentrated $(96 \%)$ sulfuric acid $\mathrm{H}_{2} \mathrm{SO}_{4}[12 ; 13]$.

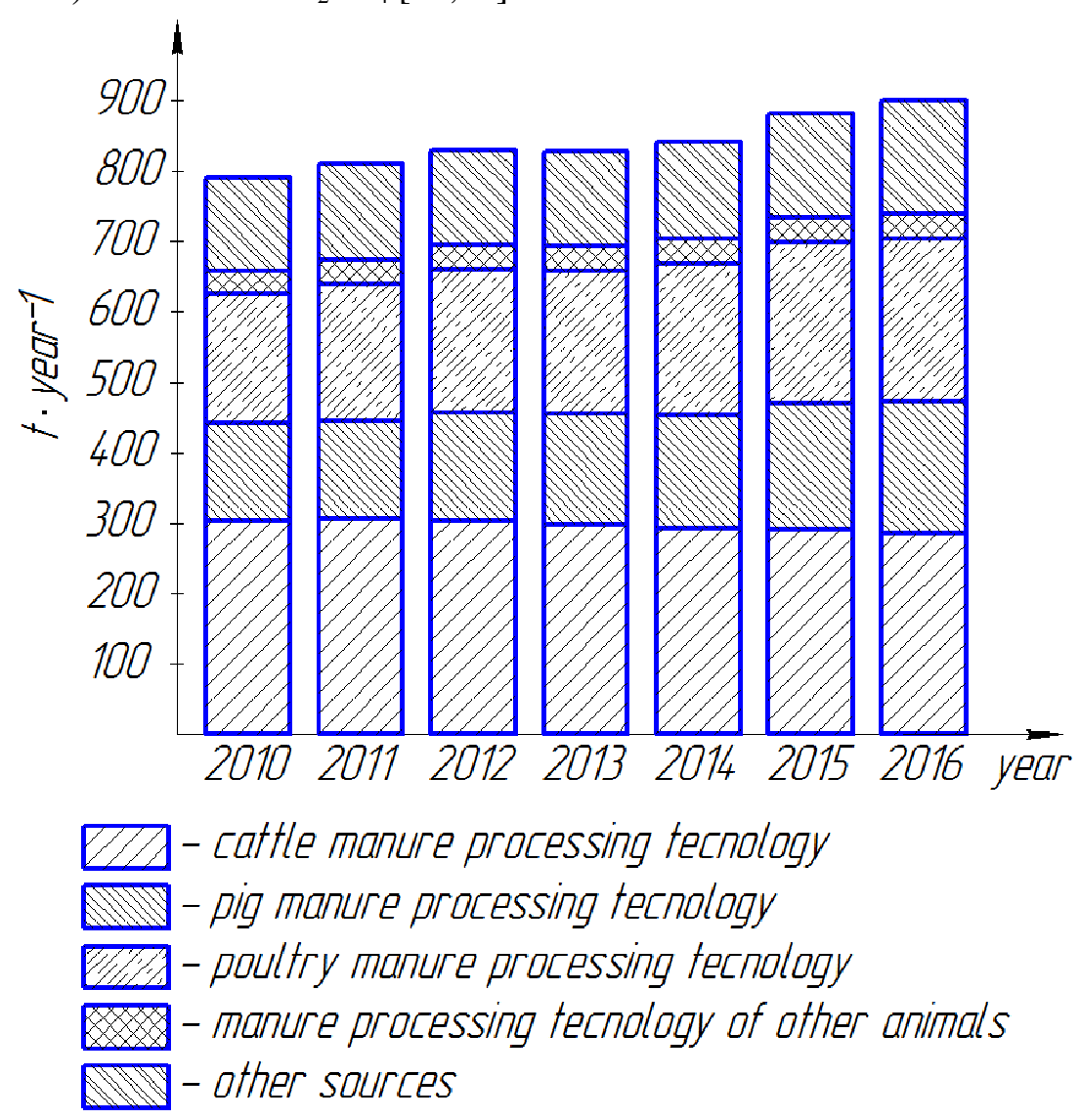

Fig. 1. Ammonia emission from various sources in Russia

Since 2010, this technique has been used in Denmark. Today, about $20 \%$ of the slurry produced in Denmark is processed using the acidification technology on 325 installations [14].

For assessing the possibilities of using slurry acidification techniques at large-scale livestock enterprises in the Russian part of the Baltic Sea catchment area, it is firstly necessary to evaluate the possible risks associated with the use of these techniques, and roughly calculate the possible costs.

\section{Materials and methods}

The study is a theoretical survey; it was based on the materials obtained by the researchers of IEEP - branch of FSAC VIM when evaluating the prospects for the use of slurry acidification techniques in the North-West Region of Russia and the project "Bringing Russia and Belarus into Baltic Slurry Acidification" for the territory of the subjects of the Russian Federation within the Baltic Sea catchment area.

The analysis was based on an assessment of the impact of the proposed technological solutions implementation on the environment and the final profitability of agricultural production, developed within the project. During evaluation technical, economic and legislation aspects were assessed using the expert-based approach.

To date, there are three variants of slurry acidification [14]:

- In-house acidification (Figure 2a): sulfuric acid (96\%) is added to slurry in a processing tank outside the livestock house to get $\mathrm{pH}=5.5$ with simultaneous mixing. Part of the slurry is pumped back into the animal house, where it is mixed with the newly produced slurry and is removed to the storage. The average sulfuric acid application rate is $41 \cdot \mathrm{t}^{-1}$ of slurry. 
- In-storage acidification (Figure $2 b$ ): sulfuric acid (96\%) is added to a storage tank or lagoon with vigorous mixing to get $\mathrm{pH}=6$. The main limiting factor is abundant foaming from the acid and slurry interaction. It is possible both to acidify the total amount of slurry in the main storage and to intensively acidify the part of the slurry in the intermediate tank, and then mix it with the main amount. The acid consumption is 3-4 liters per 1 ton of slurry.

- In-field acidification (Figure 2c): sulfuric acid (96\%) is added directly, when the slurry is applied on the field by a mixer teamed with a machine for applying liquid organic fertilizers. The acid consumption is $2-3$ liters per 1 ton of slurry to achieve $\mathrm{pH}=6.4$.

a)
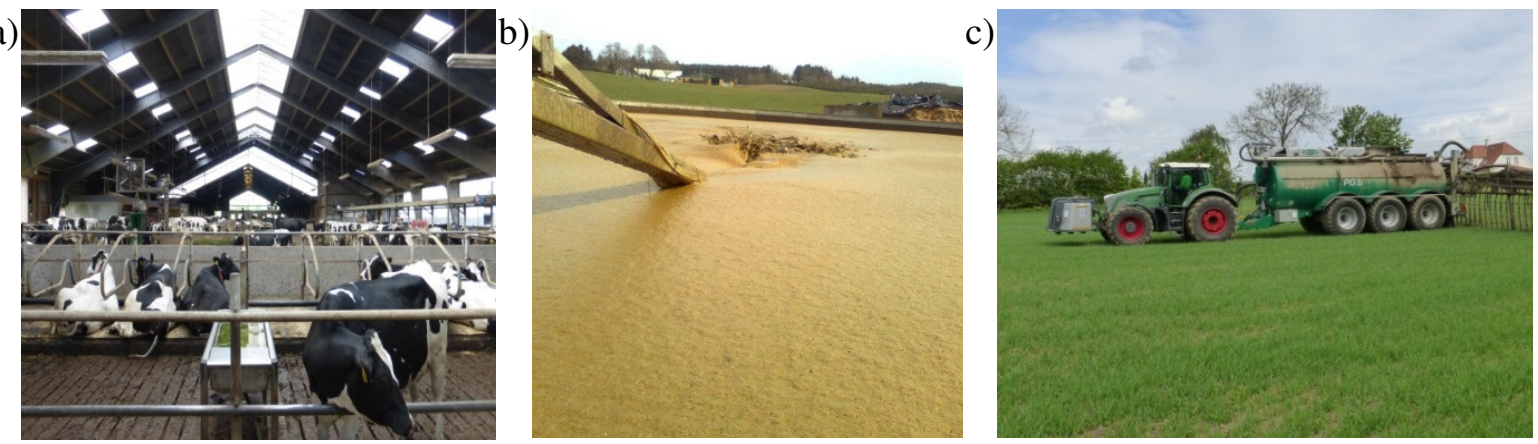

Fig. 2. Applicable acidification techniques: $\mathrm{a}-$ in-house; $\mathrm{b}$ - in-storage; $\mathrm{c}-$ in-field

Sulfuric acid is generally applied, since it is easy to use, affordable and relatively cheap. Besides, sulfur can be used for crop nutrition instead of mineral additives.

\section{Results and discussion}

Preliminary analysis of the existing conditions for the adoption of slurry acidification techniques in the territory under consideration showed that at present there are no strict requirements in Russian legislation for the farmers to introduce environmentally-friendly technologies. Of great concern is the unpleasant odour associated with the manure processing. According to the questioning conducted by the IEEP researchers, almost all farms are interested in solving this problem.

The situation should change with transfer to the best available techniques system (BAT) in intensive livestock and poultry farming that provides for tightening of requirements for newly built and reconstructed agro-industrial complexes. In particular, pig-breeding complexes for fattening with the capacity of over 2000 heads and multiplication farms with the capacity of over 750 sows as well as poultry factories with the capacity above 40000 heads of one-time housing, fall under their action $[15 ; 16]$.

At the same time, the current regulatory and legal framework and sanitary-epidemiological legislation do not directly prohibit the introduction of any of the slurry acidification options.

Considering the high cost of slurry storage covering, acidification can be an alternative solution with lower capital and operating costs and additional benefits associated with increased nitrogen and sulfur content in the organic fertilizer that, in turn, should lead to higher crop yields and lower feed and mineral fertilizer costs.

The results of two-year field experiments to assess the effect of acidified slurry on the yield of various crops in general confirm an increase in this indicator. An experiment in Sweden in 2016 confirmed an increase in the yield of perennial grasses by $8 \%$ as a result of acidified slurry application compared to non-acidified slurry. Similar studies in 2017 also showed no drops in the grass yields under various fertilizers application, including mineral ones [17].

On the other hand, acidification is a rather dangerous procedure, primarily for the personnel of the enterprise involved in this work. It should be noted that at the moment there is no information about the incidents that resulted in harm to personnel during slurry acidification. However, this technology is widely used only in Denmark. Analysis of the Russian legislation showed that the use of sulfuric acid in agriculture is allowed provided that the requirements for work involving the use of highly hazardous substances are met. 
Also, the negative aspects of the acidification technology include the need for additional liming to compensate for excess acidity, which is extremely important for acidic soils of North-West Russia. According to the calculations made in the above project, 1 to $1.8 \mathrm{~kg}$ of lime per liter of acid consumed will be required depending on the type of soil [18].

So, the slurry acidification techniques have both advantages and disadvantages, associated, primarily, with increased risks of emergency situations when dealing with such particularly dangerous substances as sulfuric acid.

One of the most important integral indicators of the technique efficiency is the introduction and operation costs. According to the preliminary calculations made with the use of the model of the Estonian Crop Research Institute and the data of the Federal State Budget Scientific Institution Northwest Research Institute Economy and Organization of Agriculture, the estimated payback period of the in-storage slurry acidification technique on a Russian farm with 1000 dairy cows will be about 1.25 years $[10 ; 19]$. The estimated payback period of the in-house slurry acidification will be a little less than 16 years. It is associated with high capital costs on the construction and purchase of imported acidification equipment that makes this option the least attractive of the three techniques from an investment point of view. In case of in-storage slurry acidification, the cost reduction against the traditional storing of not-acidified slurry in an open storage will be 0.47 EUR per $1 \mathrm{~m}^{3}$ of slurry. The cost reduction is mainly owing to no need of ploughing-in the acidified slurry introduced by the hoses, as well as owing to the savings on the purchase of sulfur and mineral (nitrogen) fertilizers to compensate for nitrogen loss. At the same time, the cost of additional liming will be about 0.1 EUR per $1 \mathrm{~m}^{3}$ of slurry.

The economic assessment contains a large number of assumptions taken on the basis of the research in the EU countries (for example, the level of nitrogen losses at various stages of slurry handling).

\section{Conclusions}

1. Russian agro-industrial enterprises are faced with the need to reduce nitrogen emissions and odour associated with manure processing. Many farmers are interested in the processing techniques, which would help to address these problems. Slurry acidification may be one solution.

2. The slurry acidification techniques have positive and negative aspects, associated, primarily, with increased risks of emergency situations when dealing with such particularly dangerous substances as sulfuric acid.

3. Preliminary assessment of the economic efficiency of use of the acidification technology on a simulated Russian dairy farm with 1000 cows showed that the estimated payback period of the instorage slurry acidification technique will be about 1.25 years, in-house acidification technique just less than 16 years - taking in account the reduction of the current costs of slurry application, purchasing sulfur and nitrogen fertilizers and the difference in the capital costs.

4. Complex studies of the effectiveness of different slurry acidification techniques, taking into account the climatic and production conditions of North-West Russia are required for more accurate assessment of the profitability of the acidification technology at large-scale agricultural enterprises in the Russian part of the Baltic Sea catchment area.

\section{References}

[1] Officially reported emission data. [online] [12.12.2018] Available at: http://www.ceip.at/ ms/ceip_home1/ceip_home/data_viewers/official_tableau/.

[2] Foged H.L., Oblomkova N. Status for air quality in the Baltic Sea region with respect to ammonia. [online] [04.11.2018] Available at: http://balticslurry.eu/wp-content/uploads/ 2017/03/ARTICLE-Status-for-air-quality-in-BSR-with-respect-to-ammonia.pdf.

[3] Markovic M.Z. et al. Measurements and modeling of the inorganic chemical composition of fine particulate matter and associated precursor gases in California's San Joaquin Valley during CalNex 2010 // Journal of Geophysical Research: Atmospheres. 2014. Vol. 119. Issue 11. pp. 6853-6866. DOI: 10.1002/2013JD021408. 
[4] Kang Y. et al. High-resolution ammonia emissions inventories in China from 1980 to 2012 // Atmospheric Chemistry and Physics. 2016. Vol. 16. Issue 4. pp. 2043-2058. DOI: 10.5194/acp16-2043-2016.

[5] Paulot F. et al. Ammonia emissions in the United States, European Union, and China derived by high-resolution inversion of ammonium wet deposition data: Interpretation with a new agricultural emissions inventory (MASAGE_NH3) // Journal of Geophysical Research: Atmospheres. 2014. Vol. 119. Issue 7. pp. 4343-4364. DOI: 10.1002/2013JD021130.

[6] Wentworth G.R. et al. Soil-atmosphere exchange of ammonia in a non-fertilized grassland: measured emission potentials and inferred fluxes // Biogeosciences. 2014. Vol. 11. Issue 20. pp. 5675-5686. DOI: 10.5194/bg-11-5675-2014.

[7] Поголовье скота и птицы в хозяйствах всех категорий. Единая межведомственная информационно-статистическая система Федеральной службы государственной статистики. (Livestock and poultry population in farms of all categories. Unified Interdepartmental Information-Statistical System (UIIS)). [online] [12.01.2019] Available at: https://fedstat.ru/indicator/31325.

[8] Брюханов А.Ю. Методы проектирования и критерии оценки технологий утилизации навоза, помета, обеспечивающие экологическую безопасность. (Design methods and evaluation criteria for manure utilization technologies ensuring environmental safety). Thesis for the degree of Doctor of Sciences (Engineering). St. Petersburg, 2017. 440 p. (In Russian).

[9] Market potential analysis: Slurry acidification technologies in the Baltic Sea Region. Editors: Neumann S., Zacharias M., Stauss R., Foged H. Sweden, Uppsala: RISE, 2017. 140 p.

[10] Уваров Р.А., Обломкова Н.С., Пономарев М.А. Анализ возможностей применения технологии подкисления жидкого навоза для Северо-Запада России. (Feasibility study of slurry acidification technology for the North-West of Russia). Technologies, machines and equipment for farm crop and livestock production. 2018, N86, pp. 261-269. DOI: 10.24411/01315226-2018-10114 (In Russian).

[11] Jarvis S.C., Pain B.F. Ammonia emission from agricultural land. Proceedings Fertility Society. 1990. No. 298. England, Peterborough: Greenhill House. 35 p.

[12] Kai P. et al. A whole-farm assessment of the efficacy of slurry acidification in reducing ammonia emissions // European Journal of Agronomy. 2008. Vol. 28. Issue 2. pp. 148-154. DOI: 10.1016/j.eja.2007.06.004.

[13] Fangueiro D., Hjorth M., Gioelli F. Acidification of animal slurry - a review // Journal of Environmental Management. 2015. Vol. 149. pp. 46-56. DOI: 10.1016/j.jenvman.2014.10.001.

[14] Acidification of animal slurry. [online] [12.02.2019] Available at: http://balticslurry.eu/wpcontent/uploads/2016/10/BSA-Intro-Kiel-2018.09.27_Erik-Sindhoj.pdf.

[15] Информационно-технический справочник по наилучшим доступным технологиям: ИТС 412017 «Интенсивное разведение свиней». (BAT Information and Technical Reference Book 412017 "Intensive pig rearing"). Moscow: BAT Bureau, 2017. 303 p. (In Russian).

[16] Информационно-технический справочник по наилучшим доступным технологиям: ИТС 422017 «Интенсивное разведение сельскохозяйственной птицы». (BAT Information and Technical Reference Book 42-2017 "Intensive poultry rearing”). Moscow: BAT Bureau, 2017. 129 p. (In Russian).

[17] Slurry Acidification - Swedish Field Trials 2016 \& 2017, preliminary results. [online] [18.03.2019] Available at: http://balticslurry.eu/wp-content/uploads/2017/10/Swedish-fieldtrials.pdf.

[18] Hansen M.N., Knudsen L. Notat om anvendelse af gylleforsuring i Dansk landbrug (Memo about the use of slurry acidification in Danish farming) // Potentielle miljøeffekter ved anvendelse af forsuret gylle på landbrugsjord. [online] [17.02.2019] Available at: https://dce2.au.dk/ pub/SR257.pdf. (In Danish).

[19] Economic analyses of using of slurry acidification technologies in BSR region. Editors: Kalvi Tamm, Raivo Vettik (in preparation). 